\begin{tabular}{|l|l|l|}
\hline \multicolumn{2}{|c|}{ PublisherInfo } \\
\hline \hline PublisherName & $:$ & BioMed Central \\
\hline \hline PublisherLocation & $:$ & London \\
\hline \hline PublisherImprintName & $:$ & BioMed Central \\
\hline \hline
\end{tabular}

\title{
Autoreactive marginal B cells in drug-induced lupus
}

\begin{tabular}{|l|l|l||}
\hline \multicolumn{2}{|c|}{ ArticleInfo } \\
\hline \hline ArticleID & $:$ & 296 \\
\hline \hline ArticleDOI & $:$ & $10.1186 /$ ar-2002-73050 \\
\hline \hline ArticleCitationID & $:$ & 73050 \\
\hline \hline ArticleSequenceNumber & $:$ & 49 \\
\hline \hline ArticleCategory & $:$ & Paper Report \\
\hline \hline ArticleFirstPage & $:$ & 1 \\
\hline \hline ArticleLastPage & $:$ & 3 \\
\hline \hline & & RegistrationDate : 2001-11-30 \\
ArticleHistory & $:$ & Received \\
& Accepted 2001-11-30 & $: 2002-1-9$ \\
& $:$ & OnlineDate $\quad: 2002-1-9$ \\
\hline \hline ArticleCopyright & $:$ & Biomed Central Ltd2002 \\
\hline \hline ArticleGrants & $:$ & \\
\hline \hline
\end{tabular}




\begin{tabular}{|l|l|l|}
\hline ArticleContext & $:$ & 130754411 \\
\hline
\end{tabular}

Sylvie Fournel, ${ }^{\text {Aff1 }}$

Aff1 CNRS, Strasbourg, France

\section{Keywords}

\section{Context}

Expansion of autoreactive B cells could explain the presence of autoantibodies in the autoimmune disease, systemic lupus erythematosus (SLE). To gain better insight into the production of autoreactive $\mathrm{B}$ cells, the authors have developed a drug-induced model of lupus in BALB/c mice transgenic for the heavy chain of an anti-DNA antibody. Normally, the transgenic mice display effective regulation of the transgene-expressing anti-DNA B cells. When treated with exogenous 17'-estradiol (E2), autoreactive B cells were activated and mice developed a lupus-like disease.

\section{Significant findings}

In this model, only a small population of B cells was activated, showing that the autoimmune disease does not result in polyclonal B-cell activation. However, the splenic B-cell development is altered by E2 treatment, with a decrease in transitional B cells and an increase in marginal zone B cells. Moreover, anti-DNA secreting B cells display a marginal zone B cell phenotype. These alterations do not result from $\mathrm{CD}^{+} \mathrm{T}$-cell activation.

\section{Comments}

These results demonstrate that an autoreactive marginal zone B-cell population proliferates during SLE development, and may be mechanistically involved in disease induction. The results are very interesting and should permit insights into both the mechanism of B-cell tolerance breakdown and the 
role played by estrogens in this disease. However, these results were obtained in a nonautoimmune transgenic mouse strain, and the clinical manifestations are not spontaneous but are induced instead by a hormone.

\section{Methods}

Flow cytometry, immunochemistry, ELISPOT assay

\section{Additional information}

\section{References}

1. Grimaldi CM, Michael DJ, Diamond B: Cutting edge: expansion and activation of a population of autoreactive marginal zone B cells in a model of estrogen-induced lupus. J Immunol. 2001, 167:

1886-1890.

This PDF file was created after publication. 